\title{
De corporate psychopath als toxisch leider in academia
}

\section{Abstract}

Achter academisch wangedrag en intimidatie kan een corporate psychopath schuilgaan. Dankzij een paradoxaal persoonlijkheidsprofiel bemachtigen corporate psychopaths leidinggevende functies. Universiteiten bieden als competitieve en hiërarchische arbeidsorganisaties een geschikte arbeidsomgeving voor corporate psychopaths. In contrast met hun ogenschijnlijk succes, oefenen corporate psychopaths toxisch leiderschap uit via grensoverschrijdend gedrag zoals pesten, sexuele intimidatie en scientific sabotage. Ze veroorzaken psychosociale arbeidsbelasting van collegae en ondergeschikten en soms ook wetenschappelijk wangedrag. Bij personeelsselectie voor machtsposities alsmede in geval van ernstige sociale onveiligheid is gebruik van screeningsintrumenten voor corporate psychopathy aan te bevelen.

\section{Academische casussen van wangedrag}

Promovendi van het instituut pedagogische wetenschappen van de Universiteit Leiden gingen gebukt onder angst, intimidatie en kleinering, Volgens een intern onderzoeksrapport was er al meer dan twintig jaar een verziekte werksfeer waarvoor drie hoogleraren verantwoordelijk gehouden werden. De hoogleraar om wie het vooral draait, herkent zich niet in het beeld van een schrikbewind; hij heeft ook veel steun ${ }^{1}$.

Bij Experimentele en toegepaste psychologie aan de VU was een sfeer van verdeel-en-heers en ging een hoogleraar/afdelingsleider zich te buiten aan intimidaties en excessieve kritiek op manuscripten; er heerste een angstcultuur met verloop onder personeel. Werknemers werden misleid inzake hun eigen functie en bevorderingseisen werden opgeschroefd ${ }^{2}$.

Een charismatische hoogleraar arbeidsrecht, professioneel succesvol, maakte zich stelselmatig schuldig aan seksueel grensoverschrijdend gedrag, overvloedig drankgebruik en een tactiek van verdeel en heers waardoor een verziekte werksfeer ontstond ${ }^{3}$.

Een succesvolle hoogleraar sociale psychologie die gewerkt had aan verschillende universiteiten met onwaarschijnlijk veel publicaties op zijn naam, bleek zich over een lange periode schuldig te hebben gemaakt aan grootschalige wetenschapsfraude ${ }^{4}$.

Onlangs werd tegen een oud-decaan van Tilburg University twee jaar celstraf geëist vanwege het overmaken van grote geldbedragen aan bedrijven van familieleden. Hij had een ware promotiefabriek

\footnotetext{
${ }^{1}$ Petra Meijer en Frank Provoost: Intimidatie bij pedagogiek. Leids universitair weekblad MARE, 09/06/2016 T.Mudde: Conflict aan de Universiteit Leiden. De Volkskrant, zaterdag 27 januari 2018

${ }^{2}$ W. Visser: Waarom er zoveel onderzoekers wegliepen bij psychologie. Ad Valvas, 16 november 2020

${ }^{3}$ Hugo Logtenberg en Clara van de Wiel: Bij hoogleraar B. moesten vrouwen hoge hakken dragen. Wangedrag. De verziekte cultuur rond UvA-hoogleraar B. NRC, 15 mei 2019

${ }^{4}$ https://www.tilburguniversity.edu/nl/over/gedrag-integriteit/commissie-levelt
} 
opgetuigd; een schoonheidssalon van een familielid werd ingehuurd voor begeleiding van promovendi. Hij is veroordeeld voor valsheid in geschrifte maar vrijgesproken van oplichting van de universiteit. Zelf miskent hij dat er iets immoreels gepasseerd zou zijn ${ }^{5}$.

Achter een façade van academisch en professioneel succes schuilt in deze gevallen een werkelijkheid van grensoverschrijdend gedrag: (academisch) wangedrag en intimidatie van ondergeschikten waardoor een angstcultuur werd gecreëerd. Verdeel en heerstactiek zorgden voor inconsistentie in de beeldvorming bij medewerkers: bij sommigen adoratie en bij anderen afschuw ${ }^{6}$.

\section{Corporate psychopath: succesvolle psychopathie}

Corporate psychopaths worden - in tegenstelling tot criminele psychopaten - ook wel beschouwd als succesvolle psychopaten (Benning, Venables, \& Hall, 2018; Boddy, Clive R., 2017; Fritzon, Brooks, \& Croom, 2019). Ze manifesteren zich in bedrijven of overheidsorganisaties op het eerste gezicht innemend, maar blijken emotioneel oppervlakkig en kil, vervuld van een grandioos besef van eigenwaarde, liegen pathologisch, manipuleren en misleiden anderen omwille van exploitatie voor hun eigen gewin. Wanneer ze anderen kwetsen tonen ze geen empathie of berouw en nemen geen verantwoordelijkheid voor hun daden. Dankzij hun psychopathische trekken verwerven corporate psychopaths zich veelal machtsposities, aanzien en financieel gewin. De corporate psychopath bouwt zijn loopbaan op via sociale manipulatie in plaats van competentieontwikkeling. Zonder misdrijven te begaan, overschrijdt een corporate psychopath stelselmatig sociale normen en rechten van anderen en weet negatieve consequenties van zijn wangedrag te ontlopen.

In grote ondernemingen en competitieve omgevingen waar het doel de middelen heiligt en sprake is van groei, reorganisaties en personeelsverloop komen ze dankzij hun psychopathische trekken tot hun recht . Charme, charisma en manipulatie kunnen in context van de werkplek van nut zijn voor impressie-management omwille van zelfpromotie. In selectiegesprekken winnen ze het daardoor van anderen . Imponeergedrag gekoppeld aan nietsontziende daadkracht en oppervlakkige charme maken dat hen gemakkelijk een leiderschapspotentie wordt toegedicht. Achter dat masker weten zij hun antisociale persoonlijkheid in beginsel verborgen te houden. Ze zijn bijzonder behendig in het organiseren van een steunend netwerk en in het manipuleren en uitbuiten van collegae/ondergeschikten/werknemers, waarbij machtsverschil hen helpt. Binnen organisaties werken zij zich snel en niets ontziend omhoog, worden met hun zelfzuchtige ambities en gewetenloosheid toxische leiders en onverantwoordelijke managers om vervolgens een spoor van vernieling aan te

\footnotetext{
${ }^{5}$ https://universonline.nl/nieuws/2021/06/09/celstraf-van-twee-jaar-geeist-tegen-voormalig-decaan-arie-deruijter/ en https://www.rechtspraak.nl/Organisatie-en-contact/Organisatie/Rechtbanken/RechtbankAmsterdam/Nieuws/Paginas/Taakstraffen-voor-oud-decaan-en-familieleden-voor-valsheid-in-geschrift.aspx ${ }^{6}$ Hugo Logtenberg en Clara van de Wiel: Bij hoogleraar B. moesten de vrouwen hakken dragen; Wangedrag. De verziekte cultuur rond UvA-hoogleraar B. NRC, woensdag 15 mei 2019.
} 
richten en door te stappen naar het volgende zakelijke avontuur. Corporate psychopaths creëren een extreme werkomgeving waarin pesten, vijandigheid, angst, geringe arbeidstevredenheid en een hoog verloop van personeel heersen. Naar hoger geplaatsten weten ze een vals positieve reputatie te presenteren terwijl ondergeschikten door hen ondermijnd en ondergewaardeerd worden . Ze kiezen hun slachtoffers vanuit een goed ontwikkeld gevoel voor de waarden, motieven en zwakten van anderen, om via emotionele manipulatie en misleiding de kwetsbaarheden van anderen te exploiteren . Onder werknemers heerst vaak een tegenstrijdige beeldvorming van hen, doordat ze er met verdeel en heerstactieken voor zorgen dat favorieten vooral de façade zien terwijl zondebokken met de duistere persoonlijkheid daarachter geconfronteerd worden en daaronder lijden.

De persoonlijkheidsstoornis psychopathie is een paradoxale gesteldheid waarvan het prototype op het eerste gezicht charmant en doortastend lijkt maar bij nadere kennismaking oneerlijk, roekeloos, agressief en profiterend blijkt. Psychopathie omvat een constellatie van interpersoonlijke, affectieve, levensstijl- en gedragsaspecten alsmede een profiterende levensstijl en antisociaal gedrag .

- Interpersoonlijke factor: een overtrokken zelfbeeld, kunstmatige charme, manipulatie en leugenachtigheid.

- Affectieve factor: kilheid en ontbreken van empathie en geweten, en niet aanvaarden van verantwoordelijkheid.

- Exploiterende levensstijl: impulsiviteit en sterke behoefte aan prikkels, schaamteloos misbruik makend, zonder realistische lange termijn doelen.

- Antisociale gedragsfactor: overschrijding van andermans grenzen en tevens een gebrek aan zelfcontrole/inhibitie.

Norm overschrijdend gedrag zoals misleiding, bedrog, pesten en fraude, staan in flagrant contrast met de gunstige eerste indruk, maar schuldbesef daarover ontbreekt door een tekort in empathie en moreel redeneren.

Psychopathie vertoont overlap met cluster-B persoonlijkheidsstoornissen uit het psychiatrisch handboek DSM-5 ${ }^{7}$ : de antisociale persoonlijkheidsstoornis (ASPD) en narcistische persoonlijkheidsstoornis (NPD) . Die overlap in symptomen is gelegen in antagonistische trekken: een grandioos zelfbeeld, gebrek aan empathie, manipuleren en exploiteren van anderen. Maar psychopathie impliceert in mindere mate dan ASPD crimineel gedrag (sociaal deviant gedrag dat conflict met het strafrecht oplevert). Psychopathie vertoont meer desinhibitie en ontbrekend geweten dan NPD. Psychopathie wordt, tezamen met narcisme en Machiavellisme, aangeduid als de 'dark triade' . Machiavellisme impliceert: vanuit opportunisme manipuleren en misleiden van anderen voor eigen gewin. Narcisme behelst een patroon van zelf-idealisering, grandioos gedrag en besef overal

\footnotetext{
${ }^{7}$ Diagnostic and statistical manual of mental disorders fifth edition https://dsm.psychiatryonline.org/doi/book/10.1176/appi.books.9780890425596
} 
aanspraak op te maken . Deze duistere triade waarbinnen middelmatige correlaties bestaan (.30 voor narcisme en Machiavellisme, .51 voor narcisme en psychopatie en .59 voor Machiavellisme en psychopatie) heeft in de kern antagonisme gemeen: de tegenpool van aangenaamheid, namelijk arrogantie, kilheid, oneerlijkheid en manipulatie . Psychopathie is de meest destructieve stoornis van de dark triad vanwege de exploiterende levensstijl en de predispositie tot antisociaal gedrag . Het triarchische model van psychopathie, gaat uit van drie dimensies (Kranefeld \& Blickle, 2021; Patrick, 2019):

- onverschrokkenheid (boldness): moed, dominantie, stressbestendigheid, veerkracht

- $\quad$ ongeremdheid (disinhibition): impulsief, planloos, onverantwoordelijk, directe behoeftebevrediging

- gemeenheid (meanness): onthechtheid, gebrek aan empathie, manipulatie, bedrog en harteloosheid.

Dit driedimensioneel model levert een basis voor onderscheid tussen psychopathie en de antisociale persoonlijkheidsstoornis (ASPD): onverschrokkenheid vormt een kerndimensie in psychopathie maar niet in ASPD . In de onverschrokkenheid schuilt ook het masker van de psychopaat: charisma, dominantie, koelbloedigheid. Dat zijn de als effectief beschouwde eigenschappen van dc corporate psychopath. Desinhibitie is geassocieerd met disfunctioneel leiderschap en gemeenheid met harde beïnvloedingstaktieken. Deze componenten vormen de toxische kern van de corporate psychopath die zich manifesteert in externaliserend en antisociaal gedrag en in contraproductief werkgedrag dat zich keert tegen personeel en organisatie, zich manifesterend in misbruik, afwijking van de productienormen, sabotage, diefstal, terugtrekking .

Psychopathie komt bij ongeveer $1 \%$ van de populatie voor en dat geldt ook onder junior personeel. Op senior-niveau maken zij 4\% van het personeel uit en onder CEO's nog meer (Boddy, Clive R., 2017). Van gevangenispopulaties maken psychopaten 20-30\% uit, beduidend minder dan de antisociale persoonlijkheidsstoornis die daar geschat wordt op $47-75 \%$. Meer dan $10 \%$ van de werknemers krijgt met een psychopaat te maken ..

Of bij succesvolle psychopathie, ondanks de antisociale psychopathische kern, sprake is van een subklinische vorm, van modererende gunstige factoren (zoals intelligentie, sociaaleconomische status, specifieke beroepen) of van een voor adaptief functioneren gunstiger profiel van psychopathische trekken (interpersoonlijke en affectieve psychopathische kenmerken, zonder executieve functietekorten ${ }^{8}$ ), is de vraag. Als succesprofiel voor ondernemerschap en politiek leiderschap geldt de combinatie van een laag angstniveau (door onder-reactiviteit bij risico of gevaar) met de affectieve

\footnotetext{
${ }^{8}$ In het triarchisch model van psychopathie bestaat het profiel van succesvolle psychopathie uit onverschrokkenheid en gemeenheid, zonder desinhibitie. Dat resulteert in geringe angst, ontbrekende empathie en instrumentele agressie, maar minder in middelenverslaving en impulsief antisociaal gedrag.
} 
en interpersoonlijke psychopathische trekken dat hen in staat stelt tot onderkoeld doelgericht handelen onder stresserende omstandigheden.

Onder presidenten, CEO's en directeuren, burgemeesters, decanen zijn er een aantal geïdentificeerd .

De corporate psychopath wordt niet alleen in het bedrijfsleven en bij overheidsorganisaties gesignaleerd, maar ook bij instellingen voor hoger onderwijs .

\section{Psychopathie en toxisch leiderschap}

Psychopathische trekken kunnen makkelijk gehouden worden voor leiderschapscompetenties (Boddy, Clive R., 2017). Dat geldt met name voor charme en charisma, besluitvaardigheid en organisatiesensitiviteit. Grandioze ideeën worden als visionair beschouwd, misleiding en manipulatie voor overtuigingskracht gehouden, gebrek aan geweten en berouw voor besluitvaardigheid bij moeilijke beslissingen, snel verveeld zijn en najagen van prikkels worden voor vermogen tot multitasking aangezien. Psychopaten vinden hun weg naar leiderschap en hun leiderschap heeft veelal negatieve invloed op personeel en organisatie blijkens arbeidsontevredenheid, geringe organisatiebetrokkenheid, arbeidsdemotivatie, en vertrekintenties. Door het tegendeel van rechtvaardigheid en respect en door een werkomgeving te creëren die zich typeert door pesten en misbruik (Holland, 2020), wordt volgens de sociale uitwisselingstheorie in geval van toxisch psychopathisch leiderschap niet voldaan aan wederkerigheid in de werkrelatie waardoor het welzijn van werknemers afbreuk wordt gedaan . Hun beslissingen en strategische doelen zijn persoonlijk gemotiveerd, met focus op schijn in plaats van inhoud en gericht op de korte in plaats van op de lange termijn.

Corporate psychopathy hangt samen met de identificatie met leiderschap, maar niet met effectief (transformationeel en/of transactioneel) leiderschap, afgemeten aan het oordeel van ondergeschikten .Meta-analytisch onderzoek (Landay, Harms, \& Credé, 2019) wijst op een zwak positief verband tussen psychopathie en verwerven van leidinggevende positie (correlatie .06), een zwak negatief verband van psychopathie met effectiviteit als leidinggevende (correlatie -.04) en een middelmatig negatief verband met transformationeel leiderschap dat een vorm van dienend leiderschap is (correlatie -.18, maar -.58 bij oordeelsvorming door ondergeschikten). Effectiviteit en transformationeel leiderschap worden als best beoordeeld bij matige psychopathie; daarvoor geldt dus een curvilineair verband met psychopatie .

In termen van de kerndimensies geldt dat ongeremdheid en gemeenheid aan veel maladaptieve gedragsvormen zijn gerelateerd, maar dat onverschrokkenheid gerelateerd is aan adaptief leiderschap. Naar leiderschapsstijl kan een tweedeling worden gemaakt tussen dienend faciliterend leiderschap versus misbruikend destructief leiderschap. De kerndimensies gemeenheid en desinhibitie van het triarchisch model van psychopathie die veronachtzaming van anderen impliceren, hangen logischerwijs samen met misbruikende supervisie en agressief gedrag. Onverschrokkenheid kan 
daarentegen bijdragen aan effectief leiderschap (Sutton, A., Roche, Stapleton, \& Roemer, 2020; Uzieblo \& Smid, 2020).

Door manipulatie van hun imago en een gunstige zelfpresentatie schuiven corporate psychopaths zichzelf naar voren als leidinggevende, maar de gedeelde trekken van de kwaadaardige persoonlijkheidsstoornissen die de dark triad vormen - kil en zonder empathie, manipulatief, misleidend, exploiterend en conflict zoekend - maken hen vanwege hun schadelijke gedrag, al gauw minder geschikt, hoewel dat zowel van de gradatie van de persoonlijkheidsstoornis (klinisch versus sub-klinisch) als van de werkcontext als modererende factor afhangt (Sutton, G., 2019).

Corporate psychopathy hangt samen met de passief-agressieve of zelfs destructieve laissez-faire leiderschapsstijl (Mathieu, Neumann, Babiak, \& Hare, 2015). Corporate psychopaths en toxische leiders vertonen veel overeenkomst in symptomen:

- ze hebben een grandioos zelfbeeld en beschadigen andermans besef van eigenwaarde (door bedreiging, intimidatie en pesten),

- ze vertonen een integriteitsgebrek (bedienen zich van manipulatie en bedrog, zijn uit op rijkdom, macht en prestige, nemen geen verantwoordelijkheid en schuiven schuld op anderen)

- ze misbruiken anderen (kil berekenend en zonder zorg voor en medeleven met anderen).

Iedere corporate psychopath die een leidinggevende functie krijgt, wordt een toxische leider.

Omgekeerd is niet iedere toxische leider een psychopaat (Boddy, Clive R., 2017). De psychopathische leider zorgt er door de negatieve sociale uitwisseling met de leidinggevenden onder hem voor, dat deze managers ook een toxische leiderschapsstijl ontwikkelen (Palmer, Holmes, \& Perrewé, 2020). De corporate psychopath als leider scoort beter op management van zijn indruk, dan op prestaties en verantwoordelijkheid, oogst vooral persoonlijk gewin maar is schadelijk voor organisatiebelang en welzijn van personeel (Fritzon et al., 2019; Palmen, Derksen, \& Kolthoff, 2020; Uzieblo \& Smid, 2020). Binnen de arbeidsorganisatie zorgen ze voor ongelijke behandeling door begunstiging versus uitsluiting van werknemers en door onrechtvaardige allocatie van faciliteiten. Werknemers bestaan merendeels uit conformisten (gedreven door angst) en collaborateurs (gedreven door opportunisme) en hanteren rationalisaties voor hun tolerantie voor een destructieve leider (in de vorm van controlemythen). Non-conformisten die kritisch zijn en in verzet komen, worden vakkundig uitgeschakeld. Toxisch leiderschap ontwikkelt zich in interactie tussen een toxisch leider en de sociale omgeving. Op termijn resulteert dit in negatieve uitkomsten en in ongezonde arbeidsomstandigheden: een ziek arbeidsklimaat. Collectivistische (in tegenstelling tot individualistische) organisaties die in controle gehouden worden en waar een sterk competitieve missie geldt, lenen zich voor toxisch leiderschap (Pelletier, Kottke, \& Sirotnik, 2019; Smith \& Fredricks-Lowman, 2020).

\section{Effecten van corporate psychopaths op personeel en organisatie}

Psychopathie is sterk geassocieerd met pesten en misbruik in arbeidsorganisaties (Boddy, Clive Roland \& Taplin, 2016). Corporate psychopaths veroorzaken dankzij hun oneerlijkheid, manipulaties, 
zelfpromotie en exploitatie contraproductief werkgedrag: agressie, verzuim, verloop, sabotage en doelbewuste incorrecte werkuitvoering (Fritzon et al., 2019). Diverse onderzoeken tonen aan dat psychopathisch leiderschap arbeidstevredenheid en loyaliteit van werknemers bij de organisatie vermindert (Palmen et al., 2020). De corporate psychopath heeft een negatief effect op welbevinden van het personeel en op de productiviteit van de arbeidsorganisatie. Het onderliggend mechanisme omvat de sociale uitwisseling tussen een CEO en het topmanagement waarbij sociale normen en regels worden overschreden en het topmanagement op zijn beurt vanuit destructief leiderschap interacteert met ondergeschikten via misbruikende supervisie, slecht burgerschap, ondermijning, en agressie, resulterend in contraproductief werkgedrag van ondergeschikten. Machtsongelijkheid in de sociale uitwisselingsrelatie staat wederkerigheid van gedrag in de weg en daardoor ontstaat een cascade van contraproductief werkgedrag dat zich neerwaarts in de organisatie verplaatst wanneer een corporate psychopath een hoge machtpositie vervult, resulterend in contraproductief werkgedrag zoals sabotage, verbaal wangedrag, leugens en achterhouden van informatie, verkwisting van voorzieningen en weigeren om samen te werken en agressie De sociale uitwisselingsrelatie tussen CEO en topmanagement heeft een mediërend effect in het ontstaan van contraproductief werkgedrag (Palmer et al., 2020). De psychopathische kerndimensies desinhibitie en gemeenheid correleren in de orde van 0.24 met contraproductief werkgedrag (Kranefeld \& Blickle, 2021). Het verband tussen psychopathie en contraproductief werkgedrag valt te herleiden op de factor gemeenheid.

Psychopathie is geassocieerd met conflict (correlatie 0.563) en intimidatie en pesten op het werk (Boddy, Clive Roland \& Taplin, 2016). Daaronder vallen (seksuele) intimidatie, fysieke aanvallen, het slachtoffer tot zondebok maken en uitsluiten, frauduleus handelen (Boddy, Clive R., 2017) alsmede het opleggen van onhaalbare deadlines, van te moeilijke taken, misbruiken van HR-procedures en het doorbreken van wet- en regelgeving bij arbeidsovereenkomsten, opleggen van onbetaald overwerk, leveren van excessieve kritiek of misbruik maken van anderen (Forster \& Lund, 2018), hoge werklast, onvoldoende training en werkinstructie geven en misbruikende supervisie (Boddy, Clive Roland \& Taplin, 2016). Pesten door corporate psychopaths gebeurt veelal vanuit een leidinggevende positie en is gericht op professionele en persoonlijke ondermijning (Boddy, Clive R., Malovany, Kunter, \& Gull, 2021; Holland, 2020). 


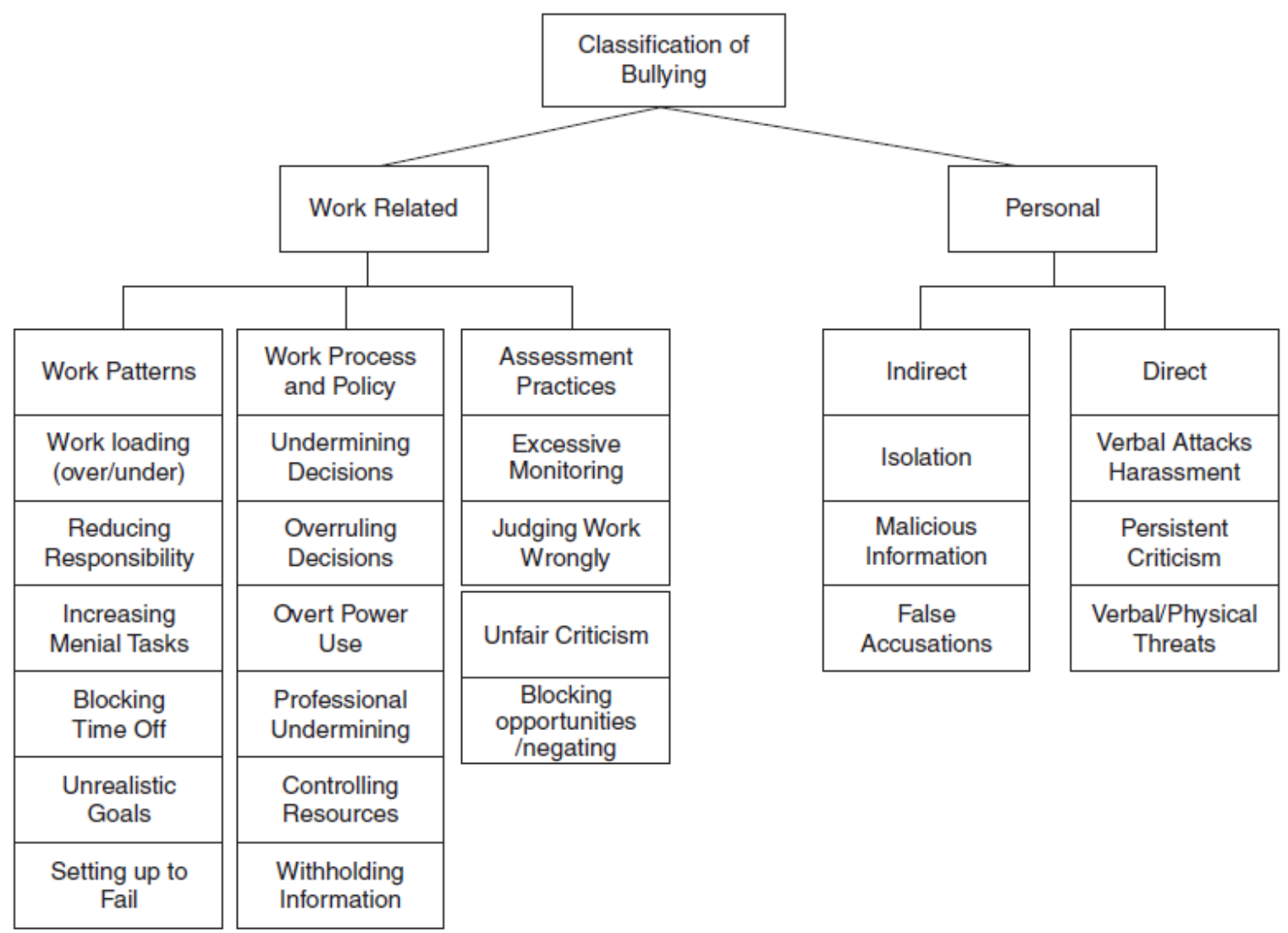

Source: Adapted from Bartlett and Bartlett (2011)

Machtsongelijkheid legitimeert de uitoefening van controle over ondergeschikten en externalisering van schuld aan organisatieproblemen. Terwijl psychopaten $1 \%$ van het personeel uitmaken en $4 \%$ van de managers, zijn zij verantwoordelijk voor $26 \%$ tot $35 \%$ van het pesten op de werkvloer (Boddy, Clive R., 2017). Pesten door psychopaten is frequenter en bedreigender en treft meerdere slachtoffers dan pesten waarbij geen corporate psychopath in het spel is. Pestgedrag van de corporate psychopath wordt door anderen veelal gekopieerd waardoor het als een virus de organisatie infecteert (Boddy, Clive Roland \& Taplin, 2016; Palmer et al., 2020).Terwijl hoger geplaatsten de corporate psychopath als ster zien, worden ondergeschikten slachtoffer (Boddy, Clive R., 2017). Pesten vindt blijkens Amerikaans onderzoek ${ }^{9}$ in $65 \%$ van de gevallen door een hogere in rang plaats. Pesten en intimidatie aan Nederlandse universiteiten gebeurt in $70 \%$ van de gevallen door supervisor of manager (Naezer, Brink, \& Benschop, 2019). Pesten is geassocieerd met ziekteverzuim, hoger verloop van personeel, productiviteitsverlies, een ziek arbeidsklimaat en psychologisch trauma, burn-out en gezondheidsschade en soms zelfs suïcide. Uit onderzoek onder universiteitspersoneel is samenhang gebleken tussen corporate psychopathy van de leidinggevende/manager en burnout van de werknemer (Oyewunmi, Akinnusi, \& Oyewunmi, 2018). De hypothese dat corporate psychopathy van managers

\footnotetext{
${ }^{9}$ Zie de 2021 WBI US workplace bullying survey: https://workplacebullying.org/wpcontent/uploads/2021/04/2021-Full-Report.pdf
} 
een voorspeller is van burnout onder werknemers werd bevestigd. In termen van het Job demandsResources model van arbeidsmotivatie c.q. arbeidsuitputting ${ }^{10}$, creëert de corporate psychopath voor veel werknemers een arbeidsklimaat vol van stressoren waar tegenover onvoldoende energiebronnen staan. Daardoor treedt een verschuiving op van arbeidsmotivatie naar arbeidsuitputting. Kenmerkend voor de relatie met een corporate psychopath is immers dat deze niet wederkerig is, maar dat sprake is van eenzijdige manipulatie, vijandigheid en exploitatie als gevolg van extreem egoïsme en ontbrekende empathie.

Verlies van welzijn van werknemers en financiële kosten voor werknemers en organisatie zijn het gevolg van pesten op het werk: de kostenschatting van pesten op het werk bedraagt voor de VS \$19 miljard per jaar ${ }^{11}$.

Het effect dat een corporate psychopath op het personeel heeft is arbeidsontevredenheid, angst, ziekte, contraproduktief werkgedrag en verloop (Sheehy, Boddy, \& Murphy, 2020).

Arbeidstevredenheid is een bepalende factor voor organisatieloyaliteit, effectiviteit en productiviteit van werknemers en is een beschermende factor tegen ziekteverzuim en verloop. Het parasitaire, manipulatieve gedrag, onrechtvaardige behandeling en misbruik door de corporate psychopath doen afbreuk aan arbeidstevredenheid. De werknemer ervaart in het ontstane toxisch arbeidsklimaat geen waardering voor zijn werk. Corporate psychopathy correleert -.655 met arbeidstevredenheid (Boddy, Clive Roland \& Taplin, 2016). Waar de corporate psychopath is, ontbreekt arbeidstevredenheid bij personeel, uitgezonderd zijn protegés (Boddy, Clive R., 2017). Misbruik en onrechtvaardige behandeling van personeel door een corporate psychopath leidt op termijn tot terugtrekking van personeelsleden uit het werk; in ziekteverzuim en verloop naar ander werk of naar werkloosheid (Boddy, Clive R., 2017). Verloop van personeel brengt hoge kosten met zich mee in de vorm van enerzijds vertrekregelingen en anderzijds wervings- en selectiekosten (Sheehy et al., 2020).

Productiviteit wordt door de corporate psychopath negatief beïnvloed door onder meer inadequate communicatie en werkinstructie, verdraaiing van feiten, werknemers geen inspraak bieden, kennissabotage en door facilitering te gebruiken als middel voor controle en manipulatie en niet als randvoorwaarde voor adequate werkuitvoering (Boddy, Clive R. et al., 2021; Sheehy et al., 2020) . Soms zijn psychopathische leiders betrokken bij witte boorden criminaliteit. Fraude is geassocieerd met corporate psychopaths (Fritzon et al., 2019; Sheehy et al., 2020). De zakenwereld biedt ruime kansen voor witte boordencriminaliteit zoals vermogensdelicten (Palmen et al., 2020).

Corporate psychopaths in senior managementposities (afdelingsvoorzitters, directeuren, dcanen), gaan over de toedeling van werklast en voorzieningen en over benoeming, beoordeling en beloning van andere werknemers. Zij bepalen in hoge mate de taakeisen waaraan werknemers moeten voldoen en de

\footnotetext{
${ }^{10}$ Zie https://www.wilmarschaufeli.nl/publications/Schaufeli/401.pdf

${ }^{11}$ Zie website Workplace bullying institute https://workplacebullying.org/
} 
hulpbronnen die daarvoor beschikbaar worden gesteld (Keashly, 2021). Door taakonduidelijkheid, inefficiëntie en parasitair misbruik van werknemers bezorgen zij werknemers een hoge werklast (Boddy, Clive R., 2017). Corporate psychopathy correleert .277 met werklast (Boddy, Clive Roland \& Taplin, 2016). Een arbeidsklimaat vol van stressoren, zoals de corporate psychopath creëert, werkt langs de fysiologische route van overproductie van cortisol. Werknemers raken gedemotiveerd en gedemoraliseerd, voelen zich afgewezen, worden boos, depressief en angstig. (Boddy, Clive R., 2017; Boddy, Clive R. et al., 2021).

Achter psychosociale arbeidsbelastingsfactoren (PSA), zoals te hoge werkdruk en sociaal ongewenst gedrag schuilt soms een psychopathische persoonlijkheidsstoornis. Een chronische negatieve uitwisselingsrelatie door een sterke discrepantie tussen inzet en opbrengst ten nadele van werknemer en gebrek aan wederkerigheid, is volgens het sociaal uitwisselingsmodel een oorzaak van burnout. Kenmerkend voor de relatie met een corporate psychopath is dat deze niet wederkerig is, maar dat sprake is van eenzijdige manipulatie, vijandigheid en exploitatie omwille van eigen gewin. Plausibel is daarom dat aan burnout relatief vaak de werkrelatie met een corporate psychopath ten grondslag ligt. De componenten van het triarchisch psychopathie-model kunnen geplaatst worden in termen van taakeisen/stressoren en hulpbronnen/energiebronnen in het job demands-resources model ${ }^{12}$ (Schaufeli $\&$ Bakker, 2013). Gemeenheid en desinhibitie zijn geassocieerd met misbruikend leiderschap en dat fungeert als een verzwaring van taakeisen. Gemeenheid van managers voorspelde bij ondergeschikten minder bevlogenheid en meer burnout. Onverschrokkenheid is geassocieerd met dienend leiderschap, dient eerder als hulpbron en voorspelde meer welzijn, betere prestatie en minder burnout (Sutton, A. et al., 2020). De componenten van het triarchisch psychopathie-model differentiëren naar hun effect op werkbeleving, in samenhang met de interpretatie ervan als taakeisen/stressoren versus hulpbronnen/energiebronnen.

${ }^{12}$ https://www.wilmarschaufeli.nl/publications/Schaufeli/401.pdf 
Figuur 2 Job demands-Resources model van arbeidsmotivatie, c.q. uitputting waarin corporate psychopathy (gemeenheid en desinhibitie) stressoren zijn; bron: Schaufeli

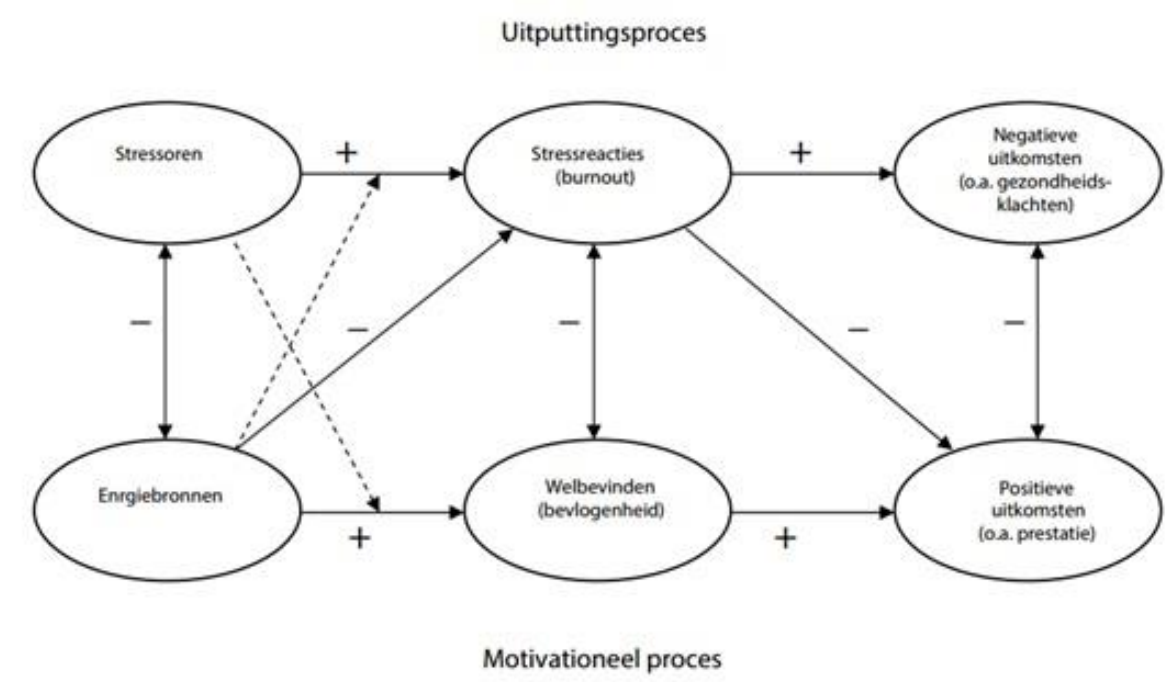

Wie klaagt wordt doelwit van pesterij (Holland, 2020). Door impressie management weet de corporate psychopath zijn contraproductieve werkgedrag achter een façade verborgen te houden en doet de organisatie doorgaans niets. Maar pesten is strijdig met de zorgplicht die de werkgever heeft (Boddy, Clive R., 2017) ter voorkoming van psychosociale arbeidsbelasting.

\section{Universiteiten als context voor corporate psychopathy}

De corporate psychopath zoekt omgevingen en rollen waarin psychopatische trekken tot hun recht komen. De perfecte werkomgeving is de combinatie van macht en chaos (Fritzon et al., 2019). Universiteiten zijn qua functiegebouw sterk hiërarchisch opgezet en vormen tevens een chaotisch geheel van tamelijk autonome eenheden. Omgevingsfactoren die toxisch leiderschap bevorderen zijn: lage culturele waarden, instabiliteit (door personeelsverloop, economische malaise, rampspoed), dreigingen (onzekere banen) en onvoldoende checks and balances (Pelletier et al., 2019). Voor structurele instabiliteit en dreiging zorgden de jarenlange bezuinigingen op het academisch onderwijs en onderzoek, terwijl de taakstelling werd uitgebreid (door toename studentenaantal, valorisatietaak en internationalisering) en recentelijk kwam daar de ontwrichting van het hoger onderwijs door de corona-pandemie nog bij. De druk die op universiteiten rust door globalisering, massificatie en bezuinigingen op de publieke investeringen bevordert pesten (Keashly, 2021).

Naast formele hiërarchische macht geldt in de academische wereld de macht van de peergroup; de professional wordt aangestuurd door een proces van peer-reviewing en collegiale besluitvorming. Peers beoordelen zowel vakinhoudelijke gedachtevorming en kennis als professioneel gedrag. Dat is niet altijd constructief, maar dwingt ook tot conformisme of tot zwijgen. De hiërarchische verhoudingen aan universiteiten gaan verder dan formele werkgeversmacht die gedelegeerd is naar 
leidinggevenden, want via mentoring, promotiebegeleiding, tenure-tracks en peer review van wetenschappelijk werk geldt een meester/gezel relatie in de vorm van supervisie met macht over iemands academische carrière en dat biedt gelegenheid voor machtsmisbruik (Keashly, 2021). Een machtsdisbalans ontstaat bovendien niet alleen door verschil in functieniveau en door supervisie, maar ook door verschil in de aard van de arbeidsrelatie doordat in de lagere wetenschappelijke rangen het grote aandeel tijdelijke dienstverbanden, dus baanonzekerheid, contamineer met ondergeschiktheid ${ }^{13}$ terwijl in de hoogste rangen het grote aandeel vaste dienstverbanden contamineert met macht ${ }^{14}$. Wie zich te weer stelt tegen de macht riskeert daardoor zijn werkzekerheid en academische loopbaan. Hoewel competitie, machtsverhoudingen en tijdelijke arbeidsrelaties contextfactoren voor pesten vormen binnen een bepaalde normatieve en discursieve context, ligt de verklaring voor pesten niet alleen in die context, maar ook in persoonlijkheidsstoornissen en in het bijzonder in persoonlijkheidsstoornissen op machtsposities. Corporate psychopathy is de verbindende schakel tussen contextfactoren en pestgedrag.

Uit reviewonderzoek naar toxisch leiderschap in het hoger onderwijs (Smith \& Fredricks-Lowman, 2020) blijkt dat dit in het hoger onderwijs relatief veel voorkomt. Toxisch leiderschap in het hoger onderwijs manifesteert zich in de organisatiecultuur, in de moraal van werknemers en in hun prestaties. De organisatiecultuur waar toxisch leiderschap bloeit is een collectivistische bedrijfscultuur waarvan de missie gepolitiseerd, tegenstrijdig en competitief is en sterke bureaucratie heerst, waar financieel beheerders belangrijke posities hebben en er via administratieve procedures micromanagement van personeel plaatsvindt, gericht op het bereiken van de missie. Onder de werknemers heerst een moraal van conformering, om problemen te voorkomen of voordeel te behalen. De werknemer raakt doordrongen van het besef dat hij vervangbaar is en dat demoraliseert. Echte prestaties tellen minder dan de schijn van prestatie, mits die missie en strategie steunt. Om dit te voorkomen zijn checks en balances nodig alsmede interpersoonlijke conflictbeheersing, balancerend tussen cooperatie en assertiviteit en tussen confrontatie en vermijding. De omstandersapathie rond pesten valt te begrijpen als collegiaal professioneel respect, mede vanuit de vrees vanwege bemoeienis met normoverschrijdingen van collegae, zelf de autonomie kwijt te raken (Keashly, 2021).

Het neoliberale bedrijfsmodel waarin personeel als kostenpost in plaats van bedrijfskapitaal wordt gezien en waar financieel beheerders leidend zijn, maakt universiteiten ontvankelijk voor toxisch leiderschap en pesten (Keashly, 2021; Smith \& Fredricks-Lowman, 2020).

In de hoog competitieve wereld van het hoger onderwijs kan een corporate psychopath zich goed omhoog werken en lijkt zijn nietsontziende doelgerichtheid succesvol. Aan sterke machtsposities zoals bestuurders en directeuren en ook hoogleraren hebben en die gaan over faciliteiten en posities van

\footnotetext{
${ }^{13}$ Van de promovendi is $100 \%$ in tijdelijke dienst en van overig wetenschappelijk personeel (docenten + onderzoekers) betreft dat 74\%, zie https://www.vsnu.nl/f c verhouding vast tijdelijk.html

${ }^{14}$ Van de hoogleraren is $8 \%$ in tijdelijke dienst en van de UHD's betreft dat $5 \%$. Zie https://www.vsnu.nl/f_c verhouding vast tijdelijk.html
} 
anderen, geen gebrek. Het internationale sterrendom van wetenschappers maakt dat het eigen gewin als ambitie niet gauw als conflicterend met het organisatiebelang wordt gezien. In competitieve context geldt het winnaars/verliezers kader, doordat de verzameling onderzoeksubsidies en bevorderingen begrensd is, en dus het succes van de een op basis van wederzijdse uitsluiting de mislukking van anderen impliceert. Vanuit zo'n positie kan een corporate psychopath zich uitleven en voor een verziekt arbeidsklimaat zorgen. (Forster \& Lund, 2018).

Pesten komt relatief veel voor in het hoger onderwijs (Forster \& Lund, 2018). Het onderzoek Harassment in Dutch academia (Naezer et al., 2019) bracht de verschillende manifestaties daarvan aan universiteiten in beeld: wetenschappelijke sabotage (om iemands carrière te dwarsbomen door iemands inzet aan het zicht te onttrekken, promotie te weigeren, het beeld te ventileren dat iemand incompetent is of iemand de toegang tot faciliteiten te blokkeren of zijn project te torpederen), seksuele intimidatie, bedreigingen, denigrerend gedrag en problematiseren van iemands speciale behoeften (functiebeperkingen). Harassment werd gedefinieerd als een gedragspatroon dat iemand in zijn waardigheid aantast of hem een vijandige werkomgeving biedt waardoor hij in zijn werk of loopbaanperspectief belemmerd wordt. Kenmerken van de academische structuur en cultuur die intimidatie en pesten bevorderen zijn: hiërarchische verhoudingen (macht versus afhankelijkheid), een sterk competitieve en prestatiegerichte geïndividualiseerde cultuur alsmede een inadequaat functionerend klachtsysteem door onder meer zelfcensuur bij slachtoffers die het klachtsysteem onderbenutten. (Naezer et al., 2019). Volgens onderzoek van promovendi netwerk Nederland ${ }^{15}$ ervaart $19 \%$ van de promovendi vormen van intimidatie (discriminatie, ongerechtvaardigd co-auteurschap, sexuele intimidatie en pesten). Uit recent internationaal reviewonderzoek blijkt dat van de academische staf $25 \%$ in de afgelopen 12 maanden pesten heeft ervaren. Dat is beduidend meer dan in de doorsnee beroepsbevolking (Keashly, 2021). Uit onderzoek onder masterstudenten en postdoc onderzoekers naar misbruikende supervisie (Moss \& Mahmoudi, 2021) bleek dat 84\% daarmee ervaring had en 59\% daarvan getuige is geweest, al was in dit onderzoek wellicht sprake van zelfselectie. Het gaat bij misbruikende supervisie om negatieve referenties, dreiging om hun functie te ontnemen, een pester die anderen tot mishandeling aanzet, ontnemen van financiering en zonder erkenning gebruiken van andermans data of prestaties; projectleiders zijn meestal de daders. Juist bij de meer prestigieuze instellingen kwam misbruikende supervisie vaker voor. Slechts $17 \%$ maakte melding van de pesterij en daarvan zegt $58 \%$ onrechtvaardig en bevooroordeeld behandeld te zijn. Gepest worden leidt tot verminderd zelfvertrouwen, aangeleerde hulpeloosheid, cynisme en burnout, ziekte, slaapgebrek en neurologische en spier- en skeletklachten, negatieve werkhouding en

\footnotetext{
${ }^{15}$ Lucille Mattijssen \& Nadine Kanbier PNN PhD Survey Asking the relevant questions Workplace malpractices: Discrimination Sexual Harassment Breaches of the Code of Conduct. Promovendi Netwerk Nederland, augustus 2020
} 
prestatiedaling en terugtrekking uit het werk. Nog geen $2 \%$ dient een klacht in over pesten (Keashly, 2021).

In context van het hoger onderwijs kunnen psychopathische trekken (egoïstich, kil, manipulatief en intimiderend, gemaskeerd door een normale façade) zich manifesteren in (Forster \& Lund, 2018):

- uitvergroten van eigen prestaties en kleineren van andermans prestaties,

- met geruchtenverspreiding reputatieschade aanrichten,

- hoge eisen aan onderzoeksprestaties stellen zonder navenant te faciliteren,

- in ruil voor positieve beoordeling of bevordering gunsten opeisen,

- zich het auteursrecht van studenten toe eigenen en de auteursvolgorde van publicaties manipuleren,

- vanuit een leidinggevende rol onrealistische tijdslimieten en taakeisen stellen,

- discrimineren en uitsluiten van werknemers,

- zonder de benodigde competenties te hebben, anderen overtuigen van de eigen meerwaarde voor de organisatie.

Er zijn twee typen wangedrag die zich bij universiteiten als kennisinstelling in het bijzonder kunnen voordoen en grote schade aanrichten: kennissabotage en wetenschapsfraude. Deze zijn ook met psychopathie geassocieerd.

In de onderlinge academische competitie is eerlijke kennisuitwisseling niet vanzelfsprekend meer en vormt kennissabotage een gevaar (Serenko \& Choo, 2020). Kennissabotage, in de zin van collegae doelbewust incorrecte informatie verschaffen of kennis voor hen verbergen die van belang is voor het werkproces, hangt samen met de dark triad persoonlijkheidsstoornissen (narcisme. Machiavellisme en psychopathie) en met een competitieve werkomgeving. Van de variantie in kennissabotage werd 50\% verklaard door de dark triad, waarvan psychopathie de sterkste voorspeller was (Karim, 2020; Serenko $\&$ Choo, 2020). Kennissabotage is in de competitieve academische omgeving een effectieve manier om collegae en ondergeschikten te ondermijnen en kan in de universitaire context bij uitstek veel schade aanrichten (Serenko \& Choo, 2020). De notie wetenschappelijke sabotage uit het LNVHrapport (Naezer et al., 2019) sluit hierbij aan en betreft naast het achterhouden van informatie, tevens aan het zicht onttrekken van iemands academische prestaties, ideeën en expertise, weigeren van iemands bevordering ondanks een vacante functie waarvoor diegene gekwalificeerd is, iemand ongefundeerd aanmerken als incompetent en torpederen van iemands onderzoeksproject.

Bij universiteiten die als bedrijven zijn ingericht en bestuurd en waar macht, prestige en onderzoeksfinanciering afhangen van eerdere wetenschappelijke prestaties, bestaat een duidelijk risico op wetenschapsfraude ${ }^{16}$. Voor wetenschapsfraude zijn, buiten de 'triangle of fraud', bestaande uit

\footnotetext{
16 "Intention [al] distortion of the research process by fabrication of data, text, hypothesis, or methods fromanother researcher's manuscript form or publication; or distortion of the research process in other ways." Bron: Samuel J. Leistedt, Paul Linkowski (2016) Fraud, individuals, and networks: A biopsychosocial model of scientific frauds. Science and Justice $56,109-112$
} 
gelegenheid, motief en rationalisatie, tevens een persoonlijkheid(sstoornis) en sociale vaardigheid nodig. Gebrek aan moraal en een manipulatieve en sociaal exploiterende aard, kwalificeren de corporate psychopath als potentiële fraudeur (Leistedt \& Linkowski, 2016). Onderzoek onder studenten toont een verband aan tussen academisch wangedrag en psychopathie (Ternes, Babin, Woodworth, \& Stephens, 2019). In een onderzoek onder biomedische wetenschappers van vier Nederlandse medische centra werd samenhang tussen academisch wangedrag en persoonlijkheidstrekken van de dark triade (psychopathy, narcisme en Machiavellisme) gevonden (Tijdink et al., 2016). Wetenschappelijk wangedrag bleek met Machiavellisme (manipulatief, kil, dominant en dwingend) geassocieerd te zijn. Zowel narcisme als wetenschappelijk wangedrag bleken meer voor te komen in hogere wetenschappelijke functies (postdocs en hoogleraren). Een antagonistische persoonlijkheid levert meer kans op wetenschappelijk wangedrag.

De competitieve context en sterk hiërarchische en tevens chaotische structuur van universiteiten zijn aanlokkelijk voor een corporate psychopath. Een buitenproportioneel aandeel van de corporate psychopath in intimidatie en pesten in universitaire context valt te verwachten Verlies van menselijk kapitaal via ziekte en personeelsverloop als gevolg van psychopathisch leiderschap, betekent bij een universiteit verlies van waardevolle gespecialiseerde professionals met reputatie, onderzoeksgeld, werkervaring en vakkennis (Sheehy et al., 2020). Wetenschappelijk wangedrag berokkent de wetenschap schade en demoraliseert het wetenschappelijk personeel. De corporate psychopath die geassocieerd is met psychosociale arbeidsbelasting voor anderen en met pesten en wetenschappelijk wangedrag, mag daarom geen blinde vlek zijn. De persoonlijkheidsstoornis van de corporate psychopath vormt een bedreiging van de sociale veiligheid aan universiteiten.

\section{Instrumenten voor detectie van psychopathie}

Omdat psychopathie en de dark triad persoonlijkheidsstoornissen sterk gerelateerd zijn aan deviant interpersoonlijk en contraproductief werkgedrag zoals agressie en pesten, fraude en anderszins ontspoord gedrag, is er een personeels- en organisatiebelang gelegen bij tijdige onderkenning en voorspelling ervan (Fritzon et al., 2019). Corporate psychopathy kan met verschillende instrumenten worden vastgesteld. Bij zelfrapportage leveren doelbewuste manipulatie en gebrek aan zelfinzicht bij psychopaten al gauw een validiteitsbeperking, reden waarom invulling door een relevante derde wenselijk is of een testvorm waarbij de meetpretentie verborgen blijft (Fritzon et al., 2019).

De Psychopathy Checklist-Revised (PCL-R) is het best onderzochte en meest gehanteerde meetinstrument voor psychopathie, maar bedoeld voor de klinische praktijk (Hare, Neumann, \& Mokros, 2018; Uzieblo \& Smid, 2020). Op basis van dossieronderzoek en klinisch interview wordt 
over items (dimensies) een dimensionele totaalscore bepaald die, om van psychopathie te kunnen spreken, boven de grensscore (30) moet uitkomen. Daarvan afgeleid is een screeningsversie: PCL-SV (Cooke, Michie, Hart, \& Hare, 1999).

De Business-Scan 360 (Mathieu, Hare, Jones, Babiak, \& Neumann, 2013) meet met 20 items corporate psychopathy, uitgaande van het vier factorenmodel dat ten grondslag ligt aan het psychopathie-concept van Hare en aan de PCL-R, maar aangepast aan de context van arbeidsorganisaties (interpersoonlijk: manipulatief/onethisch, affectief: kil/gevoelloos, levensstijl: onbetrouwbaar/ongericht, antisociaal gedrag: intimiderend/agressief),. De interbeoordelaarsbetrouwbaarheid bij beoordeling van een leidinggevende door twee ondergeschikten is .81. De B-scan 360 correleert negatief met transformationeel en transactioneel leiderschap maar positief met laissez-faire leiderschap, waaruit validiteit blijkt (Mathieu et al., 2015). De B-Scan Self voor zelfrapportage heeft een betrouwbare factorstructuur en is intern consistent. Het is een valide zelfrapportagemaat voor corporate psychopathy die positief correleert met andere maten voor psychopatie en dark triad persoonlijkheidsstoornissen en negatief met de persoonlijkheidskenmerken aangenaamheid en zorgvuldigheid (Mathieu \& Babiak, 2016). De B-scan is niet strijdig met de Americans With Disabilities Act in de VS en met de Employment Equity Act in Canada omdat deze subklinische psychopathie meet (Mathieu \& Babiak, 2016).

Op basis van het triarchisch psychopathie-model waarin onverschrokkenheid de adaptieve component vormt en gemeenheid en desinhibitie de deviante componenten zijn, is voor de werkcontext een 21items omvattende vragenlijst voor zowel zelfrapportage als invulling door een derde ontwikkeld: TriPM(work) die betrouwbaar en valide is (Sutton, A. et al., 2020).

De Corporate Personality Inventory-revised (CPI-R) is een zelfrapportage vragenlijst van 61 items, gericht op detectie van dark triad persoonlijkheidsstoornissen bij midden en hoger niveau zakelijke functionarissen. De gemeten factoren zijn impressie-management, onverschrokkenheid, interpersoonlijke dominantie en meedogenloosheid. De convergente en discriminante validiteit zijn goed. Er is tevens een versie van de vragenlijst voor derden (CPI-3R) met als factoren: adaptieve façade, meedogenloosheid en impulsief egocentrisme. De CPI-factoren komen overeen met de factoren van het triarchisch psychopathie-model (onverschrokkenheid, gemeenheid en desinhibitie). Vanwege de factor impressie management, respectievelijk adaptieve façade is de CPI geschikt voor het meten van corporate psychopathy (Fritzon et al., 2019).

Omdat psychopathie gepaard gaat met manipulatie en misleiding (impressie management) vormt faking een gevaar bij zelfrapportage meetinstrumenten voor corporate psychopathie. Daarom is een test ontwikkeld die daar minder ontvankelijk voor zou zijn: de Conditional Reasoning Test for Workplace Psychopathy (CRT-WP) waarmee corporate psychopathy wordt vastgesteld op basis van conditioneel redeneren inzake rechtvaardigingsmechanismen die inherent zijn aan psychopathie in de werkomgeving (Cook, 2019). Dit betreft: externalisering van schuld, impulsiviteit, superioriteit, risico's nemen, meedogenloze exploitatie van anderen en ontbreken van empathie. Deze rationalisaties 
zijn terug te voeren op het triarchisch psychopathie-model alsmede op het aan de PCL-R onderliggende vierfactor model van psychopathie. Door de aard van de cognitieve taak, waarbij tussen twee even logische, maar qua attitude totaal verschillende antwoordalternatieven gekozen moet worden, blijft, anders dan bij directe attitudemeting, de meetpretentie impliciet, zodat faking geen kans krijgt.

Voor selectiebeslissingen is van belang screeningsinstrumenten voor detectie van potentieel schadelijke persoonlijkheidsstoornissen te gebruiken die geschikt zijn voor de werkomgeving. Screeningsinstrumenten zouden ook predictieve validiteit moeten hebben ten aanzien van contraproductief werkgedrag. De vijf dimensies van contraproduktief werkgedrag (misbruik, afwijking van de productienormen, sabotage, diefstal, terugtrekking) kunnen gemeten worden met de Counterproductive Work Behavior Checklist (CWB-C) (Spector et al., 2006).

\section{Corporate psychopathy in juridisch kader}

Vanwege de enorme schade die aangericht wordt door corporate psychopaths (Madoff \$50 miljard; CEO Lay van het Enron-concern $\$ 40$ miljard) mogen de juridische mogelijkheden tot aanpak ervan niet onbenut blijven. Intentionele schade die een corporate psychopath toebrengt aan anderen of aan de organisatie kan mogelijk gerechtelijk afgestraft worden. De positie waar vanuit en de wijze waarop de corporate psychopath zich manifesteert, bepaalt welke rechtsgebieden relevant zijn: bestuursrecht, ondernemingsrecht en belastingrecht, arbeidsrecht of strafrecht (Sheehy et al., 2020). De taak om het welbevinden van de onderneming/organisatie te dienen, conflicteert met de tendens van de corporate psychopath om grensoverschrijdend en onverantwoordelijk louter ten gunste van eigen gewin te handelen met het financieel, materieel en menselijk kapitaal van de onderneming. Het laten prevaleren van eigen belang ten koste van het organisatiebelang en de lange termijn financiële winstgevendheid of overleving, levert conflict met het ondernemingsrecht of bestuursrecht. De onderneming moet juridisch actie ondernemen tegen een corporate psychopath die zijn macht misbruikt en het ondernemingskapitaal ten faveure van zichzelf exploiteert (Sheehy et al., 2020).

Een onveilige werkomgeving waarin werknemers psychische schade ondervinden door intimidatie, pesten, hoge werkdruk/werkstress en een angstklimaat, zoals veelal teweeg gebracht door een corporate psychopath in leidinggevende rol, is in strijd met de arbeidsomstandigheden wetgeving. De Rijksoverheid stelt inzake psychosociale arbeidsbelasting ${ }^{17}$ : "De werkgever is volgens de Arbowet verplicht om beleid te voeren, binnen het algemene arbeidsomstandighedenbeleid, dat erop is gericht om psychosociale arbeidsbelasting te voorkomen of te beperken als dit een risico vormt binnen de organisatie. Het Arbobesluit werkt deze verplichting in afdeling 4, hoofdstuk 2, artikel 2.15 verder uit

\footnotetext{
${ }^{17}$ Zie https://www.arboportaal.nl/onderwerpen/themas/psychosociale-arbeidsbelasting
} 
en verplicht werkgevers om de risico's in kaart te brengen in een Risico-Inventarisatie en -Evaluatie (Artikel 8 Arbowet). Maar ook de werknemers zelf dragen hiervoor medeverantwoordelijkheid. De werknemer is verplicht om naar zijn eigen vermogen zorg te dragen voor zijn eigen veiligheid en gezondheid en die van de andere betrokken personen (artikel 11 Arbowet)”. Over psychosociale arbeidsbelasting stelt de VSNU ${ }^{18}$ : "De universiteiten streven naar een werkklimaat, waarin het gevoel van sociale veiligheid optimaal aanwezig is. Ongewenst gedrag wordt niet getolereerd. [...] De universiteiten streven ernaar werk en werkomstandigheden aan te laten sluiten bij de kwaliteiten van medewerkers, zodanig dat werkdrukproblematiek en de negatieve gevolgen hiervan zo veel mogelijk worden voorkomen dan wel worden beperkt."

Machtsposities behoeven monitoring en tegenmacht in de vorm van controle. Naast verantwoordelijkheid voor de formele bedrijfsvoering heeft de CEO of bestuurder ook verantwoordelijkheid voor de informele bedrijfscultuur. Daarop zijn gedragscodes gericht. Monitoring betreft ziekteverlof en verloop alsmede indicatoren voor arbeidstevredenheid van werknemers (Sheehy et al., 2020).

Het probleem met rechtsmiddelen zoals klachten, aangifte, tenlastelegging, is dat ze ex post facto tot geschiloplossing met oog op rechtsherstel dienen, maar niet ex ante preventief werken. Voor werving en selectie, het belangrijkste moment voor preventief handelen, geldt gelijke behandelingswetgeving (Sheehy et al., 2020). Psychopathie is een neuropsychiatrische hersenaandoening met afwijkende responsiviteit en connectiviteit van bepaalde hersengebieden (Patrick, 2019). Persoonlijkheid valt voor de gelijke behandelingswetgeving niet onder de discriminatiegronden waartegen de AWBG bescherming biedt voor wat betreft arbeid (o.a. bij werving en selectie), maar persoonlijkheidsstoornissen vallen misschien wel onder de WGBH/CZ die inzake arbeid beschermt tegen psychische stoornis als discriminatiegrond ${ }^{19}$. De vraag is ook of met dergelijke screening binnen de personeelsselectie voldaan wordt aan het wetsvoorstel "Toezicht gelijke kansen bij werving en selectie ${ }^{20}$. Waar screening op psychopathie wettelijk belemmerd wordt, kunnen beloningsafspraken, samenwerkingsafspraken en randvoorwaarden inzake de bedrijfscultuur bij benoeming worden vastgelegd, ter inperking van schadelijk psychopathisch gedrag (Sheehy et al., 2020).

\footnotetext{
${ }^{18}$ Zie https://www.vsnu.nl/Arbocatalogus_psa.html

${ }^{19} \mathrm{https://mensenrechten.nl/en/node/675}$

${ }^{20}$ https://www.rijksoverheid.nl/actueel/nieuws/2020/07/03/wettelijke-plicht-voor-gelijke-kansen-bij-wervingen-selectie
} 


\section{Aanbevelingen voor vroegtijdig signaleren van corporate psychopathy}

Wanneer goed academisch leiderschap centraal staat bij werving, selectie en evaluatie voor de hoogste wetenschappelijke rangen, betekent dit dat kenmerken van corporate psychopathy tijdig gesignaleerd zouden moeten worden om schade te voorkomen.

Aangezien mensen met een psychopathische persoonlijkheidsstoornis zich aangetrokken voelen tot machtsposities, terwijl hun dysfunctioneel leiderschap voor personeel en organisatie destructief is, moet voorkomen worden dat zij op die machtsposities terecht komen (Holland, 2020). Bij personeelsselectie en bevorderingsbesluiten zou daarom screening op corporate psychopathy (dark triad) ingezet moeten worden ter preventie en tijdige detectie. In het sollicitatiegesprek weten narcisten en psychopaten juist een goede indruk te maken, dus dat selectiefilter volstaat niet (Mathieu \& Babiak, 2016). Omdat corporate psychopathy is geassocieerd met menselijke schade en kosten van sociaal kapitaal, moet impressiemanagement door corporate psychopaths, dat wil zeggen het manipuleren van een gunstige indruk, bij werving en selectie weinig kans van slagen hebben (Boddy, Clive Roland \& Taplin, 2016; Sutton, G., 2019). Daartoe dienen vier manieren van informatieverwerving over kandidaten (Sheehy et al., 2020):

1) Sceptische inspectie van social media op manifestatie van een grandioos zelfbeeld, excessieve zelf-promotie en respectloze commentaren over anderen, inconsistenties en vervorming van feiten.

2) De waarde van referenties onderzoeken met extra kritische blik wanneer een recruiter is ingeschakeld voor de werving en selectie, Aandachtspunt is eventuele consistenties in beeldvorming tussen aangezochte derden en aangedragen referenten.

3) Een selectiegesprek sterk structureren en alert zijn op het verleiding en charme-offensief; vragen stellen die daarvan afleiden en gericht zijn op conflicthantering, op lering trekken uit mislukkingen en vragen naar eerder personeelsverloop.

4) psychometrische testonderzoek met meetinstrumenten voor detectie van corporate psychopathy, zoals de Business-Scan 360 of de B-scan self, de TriPM(work), de Corporate Personality Inventory-revised (CPI-R of CPI-3R) of de Conditional Reasoning Test for Workplace Psychopathy (CRT-WP).

Deze vier manieren om extra informatie te verzamelen over de ware persoonlijkheid zoals die zich in feitelijk gedrag getoond heeft en/of uit inconsistenties en persoonlijkheidsonderzoek naar voren komt, moet helpen een realistisch beeld te vormen door tegenwicht te bieden aan impressie-management. Informanten uit eerdere werkomgevingen, en leden van de medezeggenschap zijn hierbij van nut.

\section{Aanbevelingen voor tegengaan van psychopathisch leiderschap}

Macht moet door voldoende tegenmacht in balans worden gehouden: door sterke medezeggenschap, daadwerkelijke academische vrijheid en werknemers wiens positie niet dermate afhankelijk is dat ze zich geen kritische houding kunnen permitteren. Toxisch leiderschap moet geen steun vinden in een 
via nepotisme benoemd netwerk van vertrouwelingen. Daarom is voor alle functies een open wervings- en selectie van belang, conform daartoe vooraf opgestelde en door medezeggenschap geaccordeerde regeling.

Neoliberale ideologie volgens welke universiteiten als bedrijven geleid zouden moeten worden, faciliteert psychopathisch leiderschap en is daarom onwenselijk. Er moet niet alleen aandacht zijn voor prestaties en resultaten, maar ook voor de manier waarop die bereikt worden (Smith \& FredricksLowman, 2020). Onderfinanciering, onzekerheid in geldstromen en onzekerheid in arbeidsrelaties bevorderen toxisch leiderschap (Pelletier et al., 2019) en zijn omstandigheden die daarom voorkomen moeten worden. Baanzekerheid door arbeidsovereenkomsten voor onbepaalde tijd maakt personeel minder kwetsbaar voor intimidaties en angstcultuur. Het beeld van wetenschap als internationale competitie met winnaars en verliezers speelt corporate psychopathy in de kaart. Dat kader werkt kennissabotage en wetenschappelijke sabotage met oog op beoordeling en bevordering in de hand (Serenko \& Choo, 2020). De beeldvorming van wetenschap als internationale competitie kan beter vervangen worden door het beeld van wetenschap als internationale zoektocht in onderlinge samenwerking naar waarheidsvinding.

Toxisch leiderschap moet geïdentificeerd kunnen worden en er moeten procedures zijn om daar melding van te maken opdat misstanden aangepakt worden. Overschrijding van normwaarden voor werkstress, arbeidsontevredenheid en ziekteverzuim, kan een indicator zijn die aanleiding kan zijn voor een onafhankelijk onderzoek naar een eventuele corporate psychopath. Destructief werkgedrag (zoals pesten, intimideren en bedreigen, kennissabotage) moeten herkend en gesignaleerd worden (Serenko \& Choo, 2020). Contraproductief werkgedrag kan vastgesteld worden met de Workplace deviance scale ${ }^{21}$. Meerdere meldingen en zeker gegrond verklaarde klachten over dezelfde leidinggevende, moeten geaggregeerd en gesignaleerd worden door de universiteit als werkgever en moeten vraagtekens doen rijzen over diens persoonlijkheid. Veelvuldig gebruik van non-disclosure agreements (veelal beëindigingsovereenkomsten als vaststellingsovereenkomst met geheimhoudingsbeding) kan een indicatie vormen voor het voorkomen van corporate psychopathy (Boddy, Clive R., 2017).

Met name HR-personeel zou geschoold moeten zijn in het herkennen van corporate psychopathy (Boddy, Clive R. et al., 2021). Een sterke machtsongelijkheid moet gecompenseerd worden door controle op corporate psychopaths en toxisch leiderschap. Leidinggevenden tussen werkvloer en corporate psychopath moeten getraind en gesterkt worden in nastreven van wederkerigheid in de

\footnotetext{
${ }^{21}$ Zie masterthesis Reinders, J. (2016) De relatie tussen morele onthechting en contraproductief werkgedrag, gemodereerd door neiging tot verloop. Arbeids- en Organisatiepsychologie, Universiteit Utrecht en Spector P. E., Fox S., Penney L. M., Bruursema K., Goh A., Kessler S. (2006). The dimensionality of counterproductivity: Are all counterproductive behaviors created equal? Journal of Vocational Behavior, 68: 446-460.
} 
sociale uitwisseling met een corporate psychopath opdat zij niet als verbindende schakel in de cascade van contraproductief werkgedrag gaan functioneren (Palmer et al., 2020) maar een buffer daartegen vormen.

De individuele werknemer die met toxisch leiderschap te maken krijgt, doet er verstandig aan om toxische situaties en gedragingen te documenteren, met de vakbondsjurist te overleggen over verdere actie en zich verder professioneel te blijven opstellen.

Escalatie van conflicten met toxische leidinggevenden moet voorkomen worden, door te kiezen voor een samenwerkende conflictoplossingsstijl en daarbij de juiste conflictthema's te bepalen in plaats van competitie, aanpassing, vermijding of compromis (Smith \& Fredricks-Lowman, 2020). Toetsing van beschadigend gedrag aan wet- en regelgeving is onverminderd relevant en het gebruik van rechtsmiddelen daartoe ook.

Toxisch leiderschap en de corporate psychopath staan in de weg aan een nieuwe balans in het erkennen en waarderen van wetenschappers ${ }^{22}$. Zij saboteren loopbaanpaden van ondergeschikten. Door verdeel- en heerstactieken is de balans tussen het individu en het collectief verstoord. Pesten, wetenschappelijke sabotage en uitsluiting maken dat kwaliteit, inhoud en creativiteit niet integer beoordeeld worden. Psychopathisch leiderschap is geen goed academisch leiderschap, maar is leiderschap dat garant staat voor systematische sociale onveiligheid.

Om echt erkennen en waarderen van wetenschappers te realiseren, is ook signalering en aanpak van corporate psychopaths nodig.

\section{Conclusies}

De persoonlijkheidsstoornis psychopathie (met narcisme en Machiavellisme 'dark triad' genoemd) die in context van regulier werk wordt aangeduid met de term corporate psychopathy, kan oorzaak zijn van sociale onveiligheid en academisch wangedrag binnen de universiteit. Door een constellatie van oppervlakkige charme, gevoelloosheid, antisociaal gedrag en gebrek aan moreel besef, belandt de corporate psychopath nogal eens op machtsposities waar zijn toxisch leiderschap het arbeidsklimaat verziekt, een angstcultuur creëert, de arbeidstevredenheid van personeel daalt en contraproduktief werkgedrag de prestaties ondermijnt. De corporate psychopath is geassocieerd met pesten, fraude en wetenschappelijke sabotage. Vanwege schade aan personeel en organisatie en de wettelijke werkgeversplicht om bronnen van psychosociale arbeidsbelasting te voorkomen, zouden dergelijke persoonlijkheidsstoornissen tijdig gedetecteerd moeten worden. Het palet aan gedrags- en

\footnotetext{
${ }^{22}$ Zie https://www.vsnu.nl/Erkennen-en-waarderen-van-wetenschappers.html position paper Ruimte voor ieders talent
} 
integriteitsregelgeving en universitaire klachtvoorzieningen volstaat niet om de schade als gevolg van corporate psychopaths te voorkomen. Het momentum voor detectie is gelegen in een kritische en zorgvuldige wervings- en selectieprocedure voor machtsposities en in persoonlijkheidsonderzoek wanneer meerdere klachtonderzoeken daartoe aanleiding geven. Tevens zou verandering van de (neoliberale) bedrijfscultuur, de financieringswijze, de machtsstructuur en competitiviteit binnen universiteiten, deze organisaties tot een minder aantrekkelijke habitat voor corporate psychopaths moeten maken. 


\section{References}

Benning, S. D., Venables, N. C., \& Hall, J. R. (2018). Successful psychopathy. In P. C. J. (Ed.), Handbook of psychopathy (second ed., pp. 585-608). New York: The Guilford Press.

Boddy, C. R. (2017). A climate of fear: Stone cold psychopaths at work Clive Boddy.

Boddy, C. R., Malovany, E., Kunter, A., \& Gull, G. (2021). Employee well-being under corporate psychopath leaders. The Palgrave Handbook of Workplace Well-Being, , 843-869.

Boddy, C. R., \& Taplin, R. (2016). The influence of corporate psychopaths on job satisfaction and its determinants. International Journal of Manpower, 37(6), 965-988.

Cook, R. (2019). Developing a faking-resistant measure of corporate psychopathy for use in employment selection: The CRT-WP. (Unpublished Masters of Science in Applied Psychology). Halifax, NS: Saint Mary's University, Halifax.

Cooke, D. J., Michie, C., Hart, S. D., \& Hare, R. D. (1999). Evaluating the screening version of the hare psychopathy Checklist—Revised (PCL: SV): An item response theory analysis. Psychological Assessment, 11(1), 3.

Forster, N., \& Lund, D. W. (2018). Identifying and dealing with functional psychopathic behavior in higher education. Global Business and Organizational Excellence, 38(1), 22-31.

Fritzon, K., Brooks, N., \& Croom, S. (2019). Corporate psychopathy: Investigating destructive personalities in the workplace Springer Nature.

Hare, R. D., Neumann, C. S., \& Mokros, A. (2018). The PCL-R assessment of psychopathy: Development, properties, debates, and new directions. In C. J. Patrick (Ed.), Handbook of psychopathy (second ed., pp. 39-79) The Guilford Press. 
Holland, P. (2020). The impact of a dysfunctional leader on the workplace: A new challenge for HRM. Personnel Review, 49(4), 1039-1052.

Karim, D. N. (2020). Effect of dark personalities on knowledge hiding behaviour at higher education institutions. Journal of Information \& Knowledge Management, 19(4), 2050031.

Keashly, L. (2021). Workplace bullying, mobbing and harassment in academe: Faculty experience. Handbooks of workplace bullying, emotional abuse and harassment (pp. 221-297) Springer.

Kranefeld, I., \& Blickle, G. (2021). The good, the bad, and the ugly? A triarchic perspective on psychopathy at work. International Journal of Offender Therapy and Comparative Criminology, , $1-25$.

Landay, K., Harms, P., \& Credé, M. (2019). Shall we serve the dark lords? A meta-analytic review of psychopathy and leadership. Journal of Applied Psychology, 104(1), 183.

Leistedt, S. J., \& Linkowski, P. (2016). Fraud, individuals, and networks: A biopsychosocial model of scientific frauds. Science \& Justice, 56(2), 109-112.

Mathieu, C., \& Babiak, P. (2016). Validating the B-Scan self: A self-report measure of psychopathy in the workplace. International Journal of Selection and Assessment, 24(3), 272-284.

Mathieu, C., Hare, R. D., Jones, D. N., Babiak, P., \& Neumann, C. S. (2013). Factor structure of the B-scan 360: A measure of corporate psychopathy. Psychological Assessment, 25(1), 288.

Mathieu, C., Neumann, C., Babiak, P., \& Hare, R. D. (2015). Corporate psychopathy and the fullrange leadership model. Assessment, 22(3), 267-278.

Moss, S., \& Mahmoudi, M. (2021). STEM the bullying: An empirical investigation of abusive supervision in academic science. Available at SSRN 3850784, 
Naezer, M., Brink, M. v. d., \& Benschop, Y. (2019). Harassment in dutch academia: Exploring manifestations, facilitating factors, effects and solutions. (). Utrecht: LNVH.

Oyewunmi, A. E., Akinnusi, D. M., \& Oyewunmi, O. A. (2018). Of predators and preys: Corporate psychopathy and employee burnout as parallels. Periodica Polytechnica Social and Management Sciences, 26(2), 149-156.

Palmen, D. G., Derksen, J. J., \& Kolthoff, E. (2020). High self-control may support 'success' in psychopathic leadership: Self-control versus impulsivity in psychopathic leadership. Aggression and Violent Behavior, 50, 101338.

Palmer, J. C., Holmes, R. M., \& Perrewé, P. (2020). The cascading effects of CEO dark triad personality on subordinate behavior and firm performance: A multilevel theoretical model. Group \& Organization Management, 45(2), 143-180.

Patrick, C. J. (Ed.). (2019). Handbook of psychopathy (second ed.). New York: The Guilford Press.

Pelletier, K. L., Kottke, J. L., \& Sirotnik, B. W. (2019). The toxic triangle in academia: A case analysis of the emergence and manifestation of toxicity in a public university. Leadership, 15(4), 405-432.

Schaufeli, W., \& Bakker, A. (Eds.). (2013). De psychologie van arbeid en gezondheid (3e ed.). Houten: Bohn, Slafleu \& Van Loghem.

Serenko, A., \& Choo, C. W. (2020). Knowledge sabotage as an extreme form of counterproductive knowledge behavior: The role of narcissism, machiavellianism, psychopathy, and competitiveness. Journal of Knowledge Management, 24(9), 2299-2325.

Sheehy, B., Boddy, C., \& Murphy, B. (2020). Corporate law and corporate psychopaths. Psychiatry, Psychology and Law, O(0), 1-29. 
Smith, N., \& Fredricks-Lowman, I. (2020). Conflict in the workplace: A 10-year review of toxic leadership in higher education. International Journal of Leadership in Education, 23(5), 538-551.

Spector, P. E., Fox, S., Penney, L. M., Bruursema, K., Goh, A., \& Kessler, S. (2006). The dimensionality of counterproductivity: Are all counterproductive behaviors created equal? Journal of Vocational Behavior, 68(3), 446-460.

Sutton, A., Roche, M., Stapleton, M., \& Roemer, A. (2020). Can psychopathy be adaptive at work? development and application of a work focused self-and other-report measure of the triarchic psychopathy model. International Journal of Environmental Research and Public Health, 17(11), 3938.

Sutton, G. (2019). The dark triad in personnel selection: An exploration of narcissism, psychopathy, and machiavellianism in candidates involved in an organisational selection process.

Ternes, M., Babin, C., Woodworth, A., \& Stephens, S. (2019). Academic misconduct: An examination of its association with the dark triad and antisocial behavior. Personality and Individual Differences, 138, 75-78.

Tijdink, J. K., Bouter, L. M., Veldkamp, C. L., van de Ven, Peter M, Wicherts, J. M., \& Smulders, Y. M. (2016). Personality traits are associated with research misbehavior in dutch scientists: A cross-sectional study. PloS One, 11(9), e0163251.

Uzieblo, K., \& Smid, W. (2020). Waarom we het vaak mis hebben over psychopathie. De Psycholoog, (3), 11-21. 